\title{
Effect of Holding Solutions on Dendrobium Orchids cv. Sonia 17 for Improving the Vase Life of Cut Spikes
}

\author{
M. Sanghamitra*, J. Dilip Babu, B.V.K. Bhagavan and D.R. Salomi Suneetha
}

Department of Floriculture and Landscaping, College of Horticulture, Dr. YSR Horticultural University, Venkataramannagudem, Tadepalligudem, West Godavari district, Andhra Pradesh, India

*Corresponding author

\section{A B S T R A C T}

\section{Keywords}

Dendrobium, Holding solutions, Vase life, Post harvest parameters

Article Info

Accepted:

04 December 2018

Available Online:

10 January 2019
Effect of holding solutions on Dendrobium orchids cv. Sonia 17 for improving vase life of cut spikes was studied. In the trail using holding solutions, $8 \mathrm{HQC}(300 \mathrm{ppm})+4 \%$ sucrose was best in achieving all parameters like Vase life (31.50), Physiological loss of weight (36.39\%), Days for fading of first flower (18.14), Days for fading of last flower (52.38), Percent bud opening per spike (86.06\%) and number of unopened and abscised buds per spike(13.88\%) on Dendrobium cut spikes cv. Sonia 17 when compared to control.

\section{Introduction}

Orchids are commercially grown worldwide as cut flower and have much demand both in domestic and international markets. Dendrobium, one of the largest genera of the family Orchidaceae, is a popular tropical Orchid, grown commercially as cut flower. In the present cut flower industry, Dendrobium $\mathrm{cv}$. Sonia 17 has taken a prominent place due to colour, attractiveness and long season of bloom. The most important barriers in the marketing and commercialization of many cut flowers are their short vase life and their inability to withstand stresses during storage or transit (Zamani et al., 2011). Correct stage of harvesting is essential as it not only influence keeping quality, but also adds to the beauty of the spike. Vase life of Dendrobiums has been much influenced by ethylene production and respiration which are the major physiological processes that are responsible for deterioration and short life. In cut flower industry about 10-30\% losses occur due to postharvest damage and mishandling practices. Further, it could be possible to extend the postharvest life of flowers by using different preservative solutions. Appropriate 
postharvest management of any cut flower is of utmost important to ensure the long lasting quality. Keeping all these considerations in view an experiment was taken up to in order to improve the vase life of cut spikes.

\section{Materials and Methods}

The cut flowers of Dendrobium Orchids cv. Sonia 17, employed for the studies were procured from the centre of excellence, Chintapalli (Visakhapatnam district). The flowers are harvested at commercial stage of harvest (2-3 unopened buds per spike) for the experiment. Immediately after harvesting, the flowers were pre-cooled by dipping the basal portions of the cut flowers in a bucket containing water, then the stem is plugged with cotton containing water and brought immediately to the laboratory for imposing the treatments. Completely randomized design was set with three replications having five spikes in each replication. Postharvest observations including Vase life, Days for fading of first flower, Days for fading of last flower, Percent bud opening per spike (\%), No. of unopened and abscised buds per spike $(\%)$, Physiological loss of weight (\%) were recorded.

\section{Results and Discussion}

The data pertaining to the effect of holding solutions on physiological loss of weight, Vase life and Days for fading of first flower of Dendrobium orchids cv. Sonia 17" is presented in Table 1. The data for physiological loss of weight was recorded on initial day and at final day. Significant differences were observed in physiological loss of weight among different treatments. Among all the treatments, significantly the minimum physiological loss of weight was observed in cut spikes held in vase solution containing 8HQC (300 ppm) $+4 \%$ sucrose $\left(\mathrm{T}_{2}\right)$ (36.39) and the maximum physiological loss of weight was observed in control $\left(\mathrm{T}_{7}\right)$ (59.40). The data for vase life was recorded from the time of keeping the flowers in vase until the first sign of wilting or fading to the death of the $50 \%$ flower petals. Significant differences were observed in vase life among different treatments. Among all the treatments, significantly the maximum vase life was observed in cut spikes held in vase solution containing 8HQC (300 ppm) $+4 \%$ sucrose $\left(\mathrm{T}_{2}\right)$ (31.50) and the minimum vase life was observed in control $\left(\mathrm{T}_{7}\right)$ (15.62).

The data for number of days taken for fading of first flower was counted and recorded. Significant differences were observed in days for fading of first flower among different treatments. Among all the treatments, significantly the maximum days taken for fading of first flower was observed in cut spikes held in vase solution containing 8HQC $(300 \mathrm{ppm})+4 \%$ sucrose $\left(\mathrm{T}_{2}\right)(18.14)$ and the minimum days for fading of first flower was observed in control $\left(\mathrm{T}_{7}\right)(10.35)$.

The data pertaining to the effect of holding solutions on days for fading of last flower, percent bud opening per spike, no. of unopened and abscised buds per spike of Dendrobium orchids cv. Sonia 17 is presented in Table 2. The number of days taken for fading of last flower was counted and recorded. Significant differences were observed in days for fading of last flower among different treatments. Among all the treatments, significantly the maximum days taken for fading of last flower was observed in cut spikes held in vase solution containing 8HQC (300 ppm) $+4 \%$ sucrose $\left(\mathrm{T}_{2}\right)(52.38)$ and the minimum days for fading of last flower was observed in control $\left(\mathrm{T}_{7}\right)$ (35.58). The data for percentage of bud opening per spike was calculated and recorded. Significant differences were observed in percent bud opening per spike among different treatments. Among all the treatments, significantly the 
maximum percent bud opening per spike was observed in cut spikes held in vase solution containing $8 \mathrm{HQC}(300 \mathrm{ppm})+4 \%$ sucrose $\left(\mathrm{T}_{2}\right)$ (86.06) which is on par with Citric acid $(400 \mathrm{ppm})+4 \%$ sucrose $\left(\mathrm{T}_{6}\right)$ and the minimum percent bud opening per spike was observed in control $\left(\mathrm{T}_{7}\right)$ (78.44). The data for number of unopened and abscised buds per spike was calculated and recorded. Significant differences were observed in number of unopened and abscised buds among different treatments. Among all the treatments, significantly the minimum number of unopened and abscised buds per spike was observed in cut spikes held in vase solution containing 8HQC (300 ppm) + 4\% sucrose $\left(\mathrm{T}_{2}\right)$ (13.88) and the maximum number of unopened and abscised buds was observed in control $\left(\mathrm{T}_{7}\right)(21.55)$.

Table.1 Effect of holding solutions on Postharvest parameters of Dendrobium orchids cv. Sonia 17

\begin{tabular}{|c|c|c|c|}
\hline Treatments & $\begin{array}{c}\text { Physiological } \\
\text { loss of weight } \\
(\%)\end{array}$ & Vase life (days) & $\begin{array}{l}\text { Days for fading } \\
\text { of first flower } \\
\text { (days) }\end{array}$ \\
\hline $\mathrm{T}_{1}: 8 \mathrm{HQC}(200 \mathrm{ppm})+2 \%$ sucrose & 41.22 & 29.38 & 16.20 \\
\hline $\mathrm{T}_{2}: 8 \mathrm{HQC}(300 \mathrm{ppm})+4 \%$ sucrose & 36.39 & 31.50 & 18.14 \\
\hline $\mathrm{T}_{3}: \mathrm{AgNO}_{3}(30 \mathrm{ppm})+2 \%$ sucrose & 55.38 & 25.07 & 12.12 \\
\hline $\mathrm{T}_{4}: \mathrm{AgNO}_{3}(40 \mathrm{ppm})+4 \%$ sucrose & 51.80 & 28.48 & 12.59 \\
\hline$T_{5}:$ Citric acid $(300 \mathrm{ppm})+2 \%$ sucrose & 45.37 & 26.43 & 14.68 \\
\hline $\mathrm{T}_{6}:$ Citric acid $(400 \mathrm{ppm})+4 \%$ sucrose & 42.92 & 29.80 & 15.55 \\
\hline $\mathbf{T}_{7}:$ Control & 59.40 & 15.62 & 10.35 \\
\hline Mean & 47.49 & 26.55 & 14.23 \\
\hline SEm \pm & 0.50 & 0.53 & 0.49 \\
\hline CD at $5 \%$ & 1.47 & 1.59 & 1.55 \\
\hline
\end{tabular}

Table.2 Effect of holding solutions on post harvest parameters of Dendrobium orchids cv. Sonia 17

\begin{tabular}{|c|c|c|c|}
\hline Treatments & $\begin{array}{l}\text { Days for fading } \\
\text { of last flower } \\
\text { (days) }\end{array}$ & $\begin{array}{l}\text { Percent bud } \\
\text { opening per } \\
\text { spike }(\%)\end{array}$ & $\begin{array}{c}\text { No. of unopened } \\
\text { and abscised } \\
\text { buds per spike } \\
(\%)\end{array}$ \\
\hline$T_{1}: 8 H Q C(200 \mathrm{ppm})+2 \%$ sucrose & 49.88 & 84.15 & 16.00 \\
\hline $\mathrm{T}_{2}: 8 \mathrm{HQC}(300 \mathrm{ppm})+4 \%$ sucrose & 52.38 & 86.06 & 13.88 \\
\hline $\mathrm{T}_{3}: \mathrm{AgNO}_{3}(30 \mathrm{ppm})+2 \%$ sucrose & 39.85 & 80.12 & 20.02 \\
\hline $\mathrm{T}_{4}: \mathrm{AgNO}_{3}(40 \mathrm{ppm})+4 \%$ sucrose & 42.70 & 82.37 & 18.15 \\
\hline$T_{5}:$ Citric acid $(300 \mathrm{ppm})+2 \%$ sucrose & 44.58 & 83.84 & 16.12 \\
\hline $\mathrm{T}_{6}:$ Citric acid (400 ppm) + $4 \%$ sucrose & 46.62 & 85.18 & 15.13 \\
\hline $\mathbf{T}_{7}:$ Control & 35.58 & 78.44 & 21.55 \\
\hline Mean & 44.51 & 82.88 & 17.26 \\
\hline SEm \pm & 0.50 & 0.40 & 0.21 \\
\hline CD at $5 \%$ & 1.58 & 1.28 & 0.67 \\
\hline
\end{tabular}


From the above results it might be concluded that holding solution of 8HQC (300 ppm) + 4\% sucrose was best regarding all the postharvest parameters. Holding solutions must essentially contain two components sugar and germicides. The sugars provide a respiratory substrate while the germicides control harmful bacteria and prevent plugging of the conducting tissue.

8 HQC along with combination of sucrose increased the fresh weight of the spike. Fresh weight retention is dependent on maintenance of carbohydrate level and water uptake. Presence of $8 \mathrm{HQC}$ in the treatments increased the water uptake, which might be due the physical and biological changes of the stem. This gives an idea about reduction in stem cell conductivity and water transportation among orchids that induced stem occlusions rather than occlusions of microbial origin. Increase in fresh weight and water uptake ultimately increased the vase life of spike when kept in vase solution containing $8 \mathrm{HQC}$ and Sucrose might be due reduced rate of senescence which improved vase life by maintaining respiration rate and cell membrane integrity. Jomy (1998) reported that the use of a combination of $4 \%$ sucrose and 400 ppm 8 HQ enhanced the vase life of Dedrobium flowers.

8HQC along with sucrose increased the days for fading of first flower, the days for fading of last flower, percent bud opening per spikes and reduced the number of unopened and abscised buds per spike might be due to high water uptake, remained flowers fresh and prevented early wilting and high carbohydrates in petal tissues enhanced bud opening and reduced unopened buds per spike.

In conclusion, the vase solution having $8 \mathrm{HQC}$ $(300 \mathrm{ppm})+4 \%$ sucrose was best in achieving all parameters when compared to 8HQC (200 $\mathrm{ppm})+2 \%$ sucrose. However increased concentration of $8 \mathrm{HQC}$ decreased the microbial growth and enhanced the vase life of cut spikes.

\section{References}

Abhimanyu chaturvedi, Anjana, N. Tripathi and Chaturvedi, S.K. 2016. Effect of plant growth regulators and floral preservatives on plant growth, spike yield and vase life of Dendrobium Orchid hybrid Sonia 17. Progressive Horticulture. 48(1).

Ajithkumar, K, Rajeevan, P.K, Sobhana, A, Sudhadevi, P.K, Sarada, S. and Simi, S. 2013. Effect of pulsing and holding solutions on vase life of Dendrobium cv. Sonia 17. Asian Journal of Horticulture. 8(2): 726-28.

Akhila Devi, R. and Jawaharlal, M. 2005. Effect of holding solution on post harvest life of cut flowers in anthurium (Anthurium andreanum Lind.) cv.Temptation. Journal of Ornamental Horticulture. 8(4): 318-19.

Jomy, T.G. 1998. Enhancement of post harvest life of Dendrobium flower. M.Sc. Thesis, Kerala Agricultural University, Thrissur, Kerela.

Miano, T.F, Rabbani, M.G. and Mondal, M.F. 2015. Vase life of Dendrobium Sonia under various holding solutions and packing materials. Science International. 27(5): 4337-4340.

Yogesh Auty, Alka Singh and Gaurang Patel. 2015. Optimization of harvest stage and improvement in the post harvest life of Orchid (Dendrobium) cut spikes with vase solution treatments. Bioinfolet. 12(4A): 823-27.

Zamini, S, Kazemi, M. and Aran, M. 2011.Post harvest life of cut rose flowers as affected by salicylic acid and glutamine. Journal of World Application Sciences. 12:1621-24.

\section{How to cite this article:}

Sanghamitra, M., J. Dilip Babu, B.V.K. Bhagavan and Salomi Suneetha, D.R. 2019. Effect of Holding Solutions on Dendrobium Orchids cv. Sonia 17 for Improving the Vase Life of Cut Spikes. Int.J.Curr.Microbiol.App.Sci. 8(01): 224-227. doi: https://doi.org/10.20546/ijcmas.2019.801.025 